\title{
THE ARMENIAN APOSTOLIC CHURCH IN THE POLITICS OF THE RUSSIAN EMPIRE: THE SEARCH FOR AN ADMINISTRATIVE OPTIMUM
}

\begin{abstract}
Amiran T. Urushadze
Southern scientific center RAS. | European University at Saint-Petersburg. Saint-Petersburg, Russia. Email: aurushadze[at]eu.spb.ru
\end{abstract}

\begin{abstract}
The article analyzes governmental debates on the functions, rights and privileges of the Armenian Catholicoi in the context of inter-institutional controversies. The author attempts to identify and analyze the most influential programmes for solving the "Echmiadzin issue" and their origins presenting at the same time certain aspects of political interaction between the Russian Empire and the Armenian Church as overlapping processes and related events. The history of relationships between Russian state and Armenian Church in XIX-XX centuries shows that different actors of the imperial politics had different ideas about the optimal model of cooperation with Echmiadzin. The divisions took place not only between the various departments (the Ministry of Internal Affairs versus the Ministry of Foreign Affairs), but also within them, where individual officials could hold "anti-departmental" views in each particular case. All this hindered administrative consolidation, slowed down the empire's response to important political challenges and dragged the imperial structures into protracted service-hierarchical confrontations. The "Etchmiadzin Question" and the governmental discussions around it show in part the administrative paralysis of the autocracy and the decompensation of the system of power in the Russian Empire in the early 20th century.

The article employs a rich documentary base of archival materials from the collections of the Russian State Historical Archive. These materials are introduced into the scholarly discourse for the first time ever.
\end{abstract}

\section{Keywords}

Caucasus; Armenian Apostolic Church; North Caucasus Frontier; Russian Empire; Armenian Catholicoi; Ethno-Confessional Policy; Historical Memory; Viceroys of the Caucasus

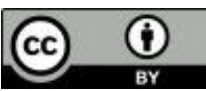

This work is licensed under a Creative Commons «Attribution» 4.0 International License 


\title{
АРМЯНСКАЯ АПОСТОЛЬСКАЯ ЦЕРКОВЬ В ПОЛИТИКЕ РОССИЙСКОЙ ИМПЕРИИ: ПОИСК АДМИНИСТРАТИВНОГО ОПТИМУМА
}

\author{
Урушадзе Амиран Тариелович \\ Южный научный центр РАН | Европейский университет в Санкт-Петербурге. \\ Санкт-Петербург, Россия. Email: aurushadze[at]eu.spb.ru
}

\section{Аннотация}

В статье представлена попытка анализа правительственных дискуссий о функциях, правах и привилегиях армянских католикосов в контексте межведомственных противоречий. Определены и рассмотрены наиболее влиятельные программы решения «эчмиадзинского вопроса», а также их происхождение. Перечисленные стороны политического взаимодействия Российской империи и Армянской церкви представлены в едином поле пересекающихся процессов и связанных событий. История взаимоотношений Российского государства и Армянской церкви в XIX - начале XX вв. показывает, что различные акторы имперской политики имели разные представления об оптимальной модели взаимодействия с Эчмиадзином. Водоразделы проходили не только между различными ведомствами (министерство внутренних дел против министерства иностранных дел), но и внутри них, когда отдельные чиновники могли придерживаться в каждом конкретном случае «антиведомственных» взглядов. Все это препятствовало административной консолидации, замедляло реакцию империи на важные политические вызовы, втягивало имперские структуры в затяжные служебно-иерархические противостояния. «Эчмиадзинский вопрос» и правительственные дискуссии вокруг него отчасти показывают административный паралич самодержавия и декомпенсацию системы власти в Российской империи начала XX в.

Статья основана на обширной документальной базе, которую составили, прежде всего, впервые вводимые в научный оборот архивные материалы из фондов Российского государственного исторического архива.

\section{Ключевые слова}

Кавказ; Армянская апостольская церковь; северокавказский фронтир; Российская империя; армянские католикосы; этноконфессиональная политика; историческая память; кавказские наместники

Это произведение доступно по лицензии Creative Commons «Attribution» («Атрибуция») 4.0 Всемирная 


\section{ВВЕДЕНИЕ}

Взаимоотношения Российского государства и Армянской апостольской (Григорианской) церкви занимают особое место в истории интеграции Кавказа в пространство империи Романовых. Духовный центр армян - Эчмиадзин - перешел под российский контроль в результате русско-персидской войны 1826-1828 гг., которая завершилась заключением Туркманчайского мирного договора 10 февраля 1828 г. И хотя армянское духовенство встречало российские войска колокольным звоном и крестным ходом, между имперской администрацией и армянскими лидерами начали проявляться недоверие и подозрительность. Главноуправляющий в Грузии и командующий Отдельный Кавказским корпусом И.Ф. Паскевич в письме к генералу И.И. Дибичу от 3 марта 1828 г. отмечал, что опасается замыслов архиепископа Нерсеса (Аштаракеци):

«На счет Нерсеса я нахожусь в большом затруднении, политика запрещает мне устранить его совершенно от дела; между тем, ежели оставить его при сем влиянии, то монастырские притязания будут бесконечны...» (АКАК, 1878, с. 486).

И.Ф. Паскевич опасался внешнеполитической самостоятельности армянского иерарха, стремления к расширению церковной собственности (на отвоеванных у Персии территориях), а также его «всегдашней наклонности к интригам» (с. 255). Российское начальство тревожилось, что своевольный и энергичный Нерсес сменит престарелого католикоса Ефрема I в качестве духовного лидера всей армянской общины.

«Если это место (армянского католикоса - А.У.) займет человек предприимчивый, склонный к интригам и упрямый, то при всех покушениях правительства к лучшему образованию духовного управления армянского, может он прибегнуть к армянам турецким и персидским и противопоставить их благим намерениям светского начальства», -

отмечал Паскевич в письме к главноуправляющему духовными делами иностранных исповеданий Д.Н. Блудову (с. 262).

В мае 1828 г. Нерсес был переведен в Бессарабию, где возглавил местную армянскую епархию. Спустя пятнадцать лет в 1843 г. архиепископа Нерсеса избрали католикосом Армянской апостольской церкви. Эта история показывает сложность взаимоотношений Российского государства и Армянской церкви. Империя стремилась использовать 
авторитет Эчмиадзина в собственных внешнеполитических интересах и, прежде всего, в качестве одного из рычагов давления на Турцию с ее многочисленной армянской общиной. Но армянские католикосы так и не стали послушным инструментом российского правительства. Независимое поведение армянских духовных лидеров, их епархиальная и школьная политика зачастую шли вразрез с имперскими управленческими принципами, создавали многочисленные конфликты с региональной и центральной администрацией государства Романовых. Во второй половине XIX в. церковь начинает играть ключевую роль в армянском национальном движении. Это вызывает еще большую тревогу российских администраторов, среди которых были сторонники как жесткой, так и мягкой политики в отношении «армянского вопроса».

В современной историографии тема взаимоотношений Российской империи и Армянской церкви регулярно привлекает внимание исследователей, что свидетельствует о ее актуальности и перспективности. Прежде всего, необходимо отметить концептуальную и фундированную статью П. Верта, в которой историк проанализировал взаимоотношения российских властей и армянских католикосов в 1828-1914 гг. Особенно значимым является вывод П. Верта об ограниченности политических возможностей российской власти в деле контроля над Армянской церковью, что стало следствием внешнеполитических мотивов (Верт, 2006, с. 137; 2012, с. 204).

К сходному выводу пришла и Е.Н. Кумпан, которая отметила также рост антиправительственных выступлений со стороны армянских политических активистов. Осторожность правительства в регулировании деятельности Армянской церкви объяснялась, по мнению Е.Н. Кумпан, в том числе опасениями революционного подъема (Кумпан, 2019).

Роли католикосов в общественно-политической жизни южной окраины империи посвящены обстоятельные статьи И.В. Амбарцумова, выделившего две основные причины конфиликта Российского государства и Армянской церкви на рубеже XIX-XX вв.: непродуманные репрессивные действия официальных властей и радикальные настроения католикоса Мкртича I (1892-1907) (Амбарцумов, 2010; 2012). В литературе анализировались и взаимоотношения католикосов с российскими властями на раннем этапе - в первой половине XIX в. Здесь необходимо отметить работы С.С. Лазаряна о проблемах взаимопонимания И.Ф. Паскевича и архиепископа Нерсеса (Лазарян, 2018) и А.В. Месропяна о церковной политике империи в Восточной Армении (Месропян, 2012). 
Краткий анализ современной историографии показывает, что исследовательское внимание сфокусировано в основном на проблемах взаимоотношений имперских институтов с одной стороны и Армянской церковью, представляемой католикосами, - с другой. Очевидно, что империя избрала сложную стратегию выстраивания своеобразного партнерства с Армянской апостольской церковью. Это совершенно не похоже на прямолинейную и жесткую ликвидацию автокефалии Грузинской православной церкви в 1811 г., прервавшую 1500-летнюю традицию независимой церкви в исторической Грузии (Рыбаков, 2012). Действительно, рассчитывая использовать Эчмиадзин как фактор внешнеполитического давления, империя ограничила себя в выборе средств административного контроля. С этим тезисом, зафиксированным в историографии, невозможно спорить, но представляется важным сделать следующий шаг. Необходимо проанализировать, как различные акторы имперской политики рефлексировали эту нестандартную имперскую ситуацию.

Кроме того, вопрос взаимоотношений с армянскими католикосами выходил далеко за пределы религиозной политики Российской империи. Успешные армянские предприниматели играли важную роль ключевых партнеров империи в деле интеграции южной окраины в состав Российского государства. Об этом можно с уверенностью говорить в отношении, к примеру, первого кавказского наместника М.С. Воронцова (1844-1853), который «завещал» своим преемникам влиятельного армянского коммерсанта И. Мирзоева: «Кто бы ни был на моем месте, я или другой, необходимо всегда будет обращаться к советам Мирзоева и к его весу в общественном мнении», - отмечал наместник в письме управляющему делами Кавказского комитета В.П. Буткову от 6 октября 1852 г. (РГИА, n.d., ф. 1250, оп. 2, д. 12, л. 12.) Во второй половине XIX в. усилилось общественное влияние армянских интеллектуалов, которые издавали несколько газет, популярных среди местного населения. В них по-разному оценивалась политика российской администрации. Церковь являлась важным элементом армянского национального движения, но далеко не единственной его движущей силой.

В предлагаемой статье представлена попытка анализа правительственных дискуссий о функциях, правах и привилегиях армянских католикосов в контексте межведомственных противоречий. Определены и рассмотрены наиболее влиятельные программы решения «эчмиадзинского вопроса», а также их происхождение. Перечисленные стороны политического взаимодействия Российской империи 
и Армянской церкви представлены в едином поле пересекающихся процессов и связанных событий.

\section{ПОИСКИ ОПТИМАЛЬНОЙ МОДЕЛИ}

В июле 1872 г. один из представителей когорты «либеральных бюрократов» А.П. Николаи, занимавший в это время должность начальника главного управления кавказского наместника, писал министру внутренних дел А.Е. Тимашеву, что только лояльный империи католикос может быть проводником российских интересов среди армянского населения Турции. В противном случае, по мнению А.П. Николаи, католикос станет стремиться к приобретению не только духовного, но и политического авторитета, что превратит его в угрозу империи (РГИА, n.d., ф. 821, оп. 138, д. 77, л. 24). А.П. Николаи жаловался на показную самостоятельность католикоса Геворга (Кеворка) IV (18651882). Особенно местную российскую администрацию нервировала

«принятая неоднократно патриархом привычка сноситься не только со своими единоверцами в Турции, но даже с турецкими министрами непосредственно от себя помимо здешнего главного начальства...» (л. 26).

Претензии, сформулированные А.П. Николаи, были небезосновательны. Геворг IV, как и его предшественники, тяготились плотной опекой российской администрации. Место армянского католикоса в имперской государственной системе, круг его полномочий и порядок избрания (фактически назначения) были определены «Положением об управлении делами Армяно-Григорианской церкви в России» от 11 марта 1836 г. (ПСЗ РИ, 1837, с. 194-209). Этот закон стал итогом многолетней работы (1829-1836) по изучению и кодификации установлений армянской церкви. Но его нормы были выработаны и на основе политической практики, а именно проведения выборов католикоса весной 1831 г. (Вартанян, 1999, с. 95-105) По точному наблюдению П. Верта, Положение 1836 г. было вполне типичным и полностью соответствовало опыту империи в регулировании конфессиональных отношений (Верт, 2006, с. 109).

Согласно «Положению», выборы католикоса проходили по многоступенчатой системе. Каждая епархия армянской церкви избирала двух депутатов (духовного и светского), которые отправлялись в Эчмиадзин. Надо отметить, что внутри Российской империи были выделены шесть армянских епархий: Нахичеванская, Бессарабская, Астраханская, Эриванская, Грузинская, Карабахская и Ширванская. В то время как турецких епархий насчитывалось 45. Это давало турецким армянам полный и решительный перевес на выборах като- 
ликоса, в сумме у них было 90 голосов из 115 (РГИА, n.d., ф. 82, оп. 138, д. 80, л. 3). Такой расклад повлиял на избрание нового католикоса в 1858 г., когда в выборах впервые активно участвовали представители турецких армян.

Депутаты от епархий совместно с эчмиадзинской духовной администрацией и местными монахами сначала избирали четырех кандидатов на патриарший престол. Затем, в ходе второго этапа голосования, из четырех избирались два кандидата. Именно эти две кандидатуры через главу кавказской администрации и Министерство внутренних дел представлялись российскому императору. Самодержец назначал католикоса из двух претендентов (ПСЗ РИ, 1837, с. 194-209). После избрания католикос должен был присягнуть на верность престолу Романовых. Такая процедура ставила главу армянской церкви в подчиненное зависимое положение. В «Положении» были зафиксированы и другие ограничения прав католикоса. Так, в случае, если католикос намеревался покинуть Эчмиадзин более чем на четыре месяца, он был обязан просить на это разрешение российского императора через Министерство внутренних дел.

Центральный институт администрации армянской церкви Эчмиадзинский синод - формировался католикосом совместно с коронной администрацией. Глава церкви представлял царю для утверждения по две кандидатуры на каждое место. Новые монастыри, церкви и семинарии могли быть открыты исключительно с санкции местной имперской администрации и МВД. Учебные планы, а также внутренний распорядок армянских духовных семинарий проходили обязательную процедуру утверждения в имперских административных институтах. Все эти многочисленные бюрократические путы должны были обеспечить лояльность армянского католикоса, за которой пристально следили региональные начальники и МВД. Но, приобретая внутриимперскую административную лояльность, католикос мог растерять международный авторитет.

Соответственно расходились и позиции различных российских государственных институтов. В министерстве иностранных дел звучали голоса, призывающие повысить авторитет эчмиадзинского престола путем расширения его административной автономии. Министерство внутренних дел и кавказская региональная администрация доказывали необходимость сохранения контроля над армянским католикосом. В 1871-1872 гг. посол в Стамбуле Н.П. Игнатьев предлагал пересмотреть Положение 1836 г. в сторону смягчения его ограничительных императивов. Кавказская администрация выступила резко против либеральной ревизии (РГИА, n.d., ф. 821, оп. 138, д. 77, 
л. 26). Обсуждалась также идея проведения в Эчмиадзине большого собора армянской церкви с участием представителей турецких, персидских и индийских епархий армянской церкви. В министерстве иностранных дел полагали, что подобный объединительный собор усилит международное влияние эчмиадзинской администрации, а кавказское начальство опасалось роста нестабильности на южной окраине империи.

Многое в отношениях региональной имперской администрации и армянского католикоса зависело от личных неформальных связей. Первому кавказскому наместнику М.С. Воронцову (1844-1854) удалось выстроить открытые, едва ли не дружеские отношения с католикосом Нерсесом V, который, еще будучи архиепископом, так нервировал И.Ф. Паскевича. Нерсес V с большим радушием встречал наместника и его жену Е.К. Воронцову в Эчмиадзине, а также организовал пышный прием цесаревичу Александру Николаевичу 6-7 октября 1850 г. Католикос даже выписал московского повара для организации питания наследника и его свиты (Ерицов, 1898, с. 40-41). М.С. Воронцов не оставался в долгу и благожелательно встречал просьбы католикоса и армянского духовенства. Так, летом 1845 г. наместник ходатайствовал к председателю Кавказского комитета и военному министру А.И. Чернышеву о возобновлении армянской церкви в Нухе (РГИА, n.d., ф. 1268 , оп. 1, д. 825 , л. 1-3). В отчете об управлении Кавказом за 1846-1848 гг. М.С. Воронцов писал:

«Назначение (курсив - Авт.) патриархом всех армян Нерсеса имело самое полезное влияние на устройство Армянской церкви и привидение дел ее в порядок. Неутомимая деятельность и заботливость этого почтенного старца дали ход многим полезным предприятиям, остававшимся до него без движения» (РГИА, n.d., ф. 1268, оп. 3, д. 22, л. 64; АКАК, 1885, с. 857).

Преемники М.С. Воронцова не смогли завязать с армянскими католикосами столь дружественных неформальных отношений. Не могли способствовать этому и большие изменения в порядке выборов главы армянской церкви, которые произошли после смерти Hepceca V.

В 1857 г. кавказский наместник А.И. Барятинский в отзыве председателю Кавказского комитета А.Ф. Орлову

«высказал мнение о желательности направить избрание католикоса на лицо из числа турецких армянских духовных сановников, дабы этим способом восстановить влияние эчмиадзинского престола на армянскую церковь в Турции, а чрез то и на армян турецко-подданных вообще» (РГИА, n.d., ф. 821, оп. 138, д. 80, л. 6.). 
Замысел А.И. Барятинского не лишен практического смысла: отношения Эчмиадзина и турецких армян были прерваны Крымской войной (1853-1856). Избрание католикосом архиепископа одной из турецких епархий Армянской церкви выглядело как надежное средство восстановить и расширить эти связи. Согласно «Записке о порядке выбора патриарха всех армян», подготовленной А.П. Николаи в 1883 г., кавказский наместник А.И. Барятинский понимал, что, инициировав избрание «турецкого» католикоса, империя может получить враждебно настроенного духовного лидера. Однако наместник рассчитывал, что эта угроза будет нивелирована большинством голосов, которое, по его ошибочному мнению, принадлежало российским армянам, а также чувством самодержавной преданности армянского населения (РГИА, n.d., ф. 821, оп. 138 , д. 80, л. 6). Расчеты эти оказались ошибочны.

Как уже отмечалось выше, выборы армянского католикоса 1858 г. прошли при абсолютном большинстве голосов представителей турецких армян (90 из 115). «Турецкие» голоса представляли российские подданные Туманов и Гургенбеков, которые получили соответствующие полномочия от армянского национального собрания в Константинополе. Католикосом всех армян единогласно избрали константинопольского патриарха Маттеоса I, который и возглавлял Эчмиадзин до своей смерти 22 августа 1865 г.

Новый католикос не стал проводником российского влияния в Османской империи. Скорее наоборот, его инициативы по пересмотру Положения 1836 г. и артикулируемое недовольство имперским контролем расшатывали лояльность российского армянского населения и вызывали тревогу администрации. Уже после смерти Маттеоса I российский посол в Стамбуле Н.П. Игнатьев отметил в одной из депеш:

«Матеос оставил нам урок, который стоит запомнить. Покровительствуемый нами и, как считалось, преданный нашим интересам, он вскоре отвернулся от нас и в конце своей жизни позволил вспыхнуть враждебным настроениям по отношению к нам» (РГИА, n.d., ф. 821, оп. 138, д. 80, л. 6).

В сентябре 1866 г. в Эчмиадзине прошли очередные выборы армянского католикоса. Они примечательны участием двух депутатов из Стамбула, которые представляли голоса «турецких» епархий. Ими являлись Сисский епископ Нерсес и коммерсант Акоп-ага Нурединсян. Характеристики представителей армянских епархий

1 «Записка» А.П. Николаи представляет значительный интерес как документ, обсуждавшийся на трех Особых совещаниях по армянским делам в 1883, 1884 и 1891 гг. 
Османской империи представлены в журнале действительного статского советника М.Е. Чиляева. Если об Акоп-аге М.Е. Чиляев отзывался как о «лице ничтожном, безвестном, бессловесном и подставном», то епископ Нерсес удостоился противоположной оценки. Российский чиновник отметил обширные познания и природный ум Нерсеса, а также призывал начальство заручиться поддержкой столь талантливого духовного лидера (РГИА, n.d., ф. 821, оп. 138, д. 87, л. 78).

Еще до прибытия стамбульских депутатов, константинопольский армянский патриарх Богос II в обращении к эчмиадзинскому синоду писал о существовании в Османской империи 65 армянских епархий, что увеличивало количество «турецких» голосов на выборах католикоса до 130 (л. 7). Кавказская администрация проигнорировала эти претензии константинопольского патриарха, но это не имело решающего значения. Новый католикос Геворг IV ранее занимал кафедру армянской церкви в Бурсе.

Геворг IV пытался балансировать: официально выражал преданность российским интересам, но на практике стремился к расширению своих прав и полномочий. Выше уже отмечалось, что Геворг IV поддерживал прямой контакт со своими влиятельными корреспондентами в Турции. Кроме того, католикос решительно выступил против подчинения армянских церковно-приходских школ российскому учебному начальству. Выдержать сложный политический баланс Геворгу IV не удалось. Российская администрация подозревала католикоса в намерении подорвать имперский суверенитет на южной окраине, а в Турции его популярность, особенно в последние годы патриаршества, пошла на убыль. Армяне Османской империи серьезно обсуждали перспективу разрыва с Эчмиадзином и признание духовного лидерства Сисского католикоса (РГИА, n.d., ф. 821, оп. 138, д. 79, л. 3).

В «Записке» А.П. Николаи подчеркивал, что и Маттеос I, и Геворг IV стремились

«придать патриаршеской власти характер не только высшего духовного, но и светско-национального главенства над армянской нацией, при возможно полной независимости от нашего правительства» (РГИА, n.d., ф. 821. оп. 138, д. 80 , л. 8).

На рубеже 1870-1880-х гг. в российских ведомствах и административных институтах, причастных к выработке правительственного курса в отношении Армянской церкви, понимали, что стратегия поддержки «турецких» претендентов показала свою несостоятельность. Начался поиск новых принципов избрания армянских католикосов. 
Российской бюрократической элите пришлось признать, что попытки использовать армянского католикоса во внешнеполитических целях провалились. Причинами этого были не только несговорчивость и честолюбие католикосов, но и внутренние политические процессы, протекавшие в Османской империи. Модернизация Османского государства (Танзимат) в годы правления султана АбдулМеджида I (1839-1861) затронула и вопрос статуса немусульманского населения. Уже Гюльханейский хатт-и шериф («благословенный указ»), обнародованный 3 ноября 1839 г., среди прочего декларировал равенство всех подданных султана вне зависимости от конфессиональной принадлежности (Петросян, 2017, с. 238-239). В условиях дипломатического противостояния накануне Парижского мирного конгресса, подводившего итоги Крымской войны (1853-1856 гг.), османское правительство 18 февраля 1856 г. обнародовало хатт-и хумаюн («высочайший указ»). Этот документ подтверждал все принципы «благословенного указа» 1839 г., а также декларировал право немусульманских религиозных общин, в том числе армянской, на широкое самоуправление (Ueno, 2016, p. 412).

Танзимат привел к своеобразному армянскому ренессансу в Османской империи (Ueno, 2013). Армянский патриарх в Константинополе превратился во влиятельную политическую фигуру, провинциальные турецкие армяне почувствовали свою связь со столичной общиной, подъем переживали армянская журналистика и искусство. Достаточно отметить, что первую профессиональную театральную труппу Стамбула, которая появилась в 1868 г., возглавил Акоп Вартовьян (Петросян, 2017, с. 247).

Турецкие армяне обрели собственное место в османском административно-правовом пространстве, что лишало российского самодержца статуса единственного защитника и покровителя армянского народа. Константинополь, а не Эчмиадзин являлся религиознополитическим центром для армянской общины обеих империй.

«При тех условиях, в которых находится ныне армянское народное управление в Константинополе, едва ли можно ожидать, чтобы патриарх константинопольский добровольно отрекся от своей давностью освященной, фактической независимости, от эчмиадзинского престола, и чтобы светское общество подчинилось влиянию духовного главы, в пределах России восседающего» (РГИА, n.d., ф. 821, оп. 138, д. 80, л. 8), -

признавалось в «Записке» А.П. Николаи.

В качестве элементов новой стратегии в отношениях с эчмиадзинскими католикосами российское правительство в 1880-х гг. обсу- 
ждало принцип невмешательства в выборы главы армянской церкви и необходимость прямого участия турецких армянских епархий в избрании католикоса. Последнее условие казалось российской правящей элите особенно важным с учетом имеющегося опыта и раскладки голосов, которые приводили к ситуации, когда выбор очередного католикоса предрешался еще в Константинополе. Российское правительство желало видеть католикосом представителя российских епархий Армянской церкви, это должно было обеспечивать соответствующую лояльность:

«Патриарх из среды русского армянского духовенства не внесет, по крайней мере в Эчмиадзин, тех прискорбных веяний, которые несутся из Босфора» (л. 13).

Однако рассматривался и другой исход выборов, при котором эчмиадзинский престол занимал армянский иерарх из турецких епархий. В этом случае со стороны имперских властей предполагалась формальная учтивость при непоколебимой твердости в принуждении католикоса следовать нормам российского законодательства. На Особом совещании по армянским делам в марте 1883 г. было принято решение «обращать главное внимание не на национальность, а на личные качества» кандидатов в католикосы.

Тогда же предлагались и более решительные, если не сказать авантюрные, варианты разрешения политического тупика в деле организации взаимодействия с армянскими католикосами. В 1882 г. едва заступивший на должность кавказского главноначальствующего князь А.М. Дондуков-Корсаков (1882-1890) представил императору Александру III «Очерк политического состояния Кавказа» (РГИА, n. d, ф. 932, оп. 1, д. 296, л. 1-14). Документ касался и «армянского вопроса». A.M. Дондуков-Корсаков отметил, что армянский католикос пользовался в Российской империи «беспримерными правами» и при этом имел на местное население «вредное для целей правительства влияние». Наибольшей опасностью, по словам А.М. Дондукова-Корсакова, был политический характер эчмиадзинского патриаршего престола, который в глазах армянского населения выступал воплощением идеи политического единства всех армян. Кавказский главноначальствующий признавал, что ранее поддержка статуса армянских католикосов как духовных лидеров всех армян - и прежде всего турецких - могла иметь перспективы. Но с приобретением в результате Танзимата турецкими армянами политических прав и привилегий, а также явными признаками мощной армянской ирреденты эта политика должна была уйти в прошлое. Вместо нее 
A.M. Дондуков-Корсаков предлагал воспользоваться уже упоминавшимся противостоянием Сисского и Эчмиадзинского патриархатов, довести его до раскола армянской церкви, а значит обеспечить и политическое разобщение армян двух империй.

«В таком случае Эчмиадзинский патриарх остался бы только духовным главой русских армян и мог бы быть поставлен, по отношению к нашему правительству и к своей пастве, в одинаковые с духовными главами других иноверческих исповеданий условия» (л. 5), -

подводил итог предлагаемой политической интриге А.М. Дондуков-Корсаков.

Идея кавказского главноначальствующего не получила продолжения. Однако само ее появление является свидетельством отсутствия у российского правительства ясного плана действий. Процесс пересмотра принципов взаимоотношений с католикосами явно затягивался, и это расширяло конфликт империи и армянской церкви.

П. Верт отметил, что к 1890-м годам российское правительство пересмотрело свое отношение к армянским католикосам и возглавляемой ими церкви. Новый правительственный курс, по мнению американского историка, привел к неудачной попытке секуляризации имущества армянской церкви в 1903-1905 гг. (Верт, 2006, с. 118). В целом, такая интерпретация верно отражает направление смены политического вектора, но упускает из виду некоторые детали и механизмы этого поворота.

В июле 1885 г. армянским католикосом стал российский подданный архиепископ Нахичевано-Бессарабской епархии Макарий, но это не привело к нормализации отношений правительства и армянского католикоса. Напротив, новый католикос прямо отвергал требования администрации, чем вызывал недовольство кавказского главноначальствующего и МВД. В начале 1891 г. правительство было вынуждено вновь вернуться к обсуждению «армянского вопроса» в рамках Особого совещания. Вопросы, вокруг которых была построена работа особого совещания, были сформулированы МВД и показывают масштаб кризиса:

«1) Не следует ли признать в настоящее время несбыточною мысль о том, что правительство может пользоваться влиянием патриарха-католикоса на заграничных армян для достижения каких-либо политических целей на Востоке?

2) Надлежит ли правительству, при выборах верховного патриарха, поддерживать какого-либо кандидата из русских или заграничных армянских духовных лиц? 
3) Необходимо ли озаботиться об уравновешивании голосов русских и заграничных армян при выборах верховного патриарха и представляется ли эта цель достижимою?

4) Какой способ следует признать наиболее удобным для прекращения произвольных распоряжений патриарха по училищным делам?

5) Какие меры следует принять в виду обнаружившегося вообще уклонения патриарха католикоса Макария от исполнения законов и требований правительства?

6) Какие распоряжения представляются необходимыми в том случае, если патриарх и Эчмиадзинский Синод, не ограничиваясь уклонениями от исполнения законов, перейдут к явному сопротивлению?» (РГИА, n.d., ф. 821 , оп. 138 , д. 80 , л. 20).

В контексте проблемы выбора лояльного католикоса наиболее важными являлись второй и третий вопросы. Подчеркнем, что они активно обсуждались уже несколько десятилетий и находились в центре внимания российского правительства и регионального начальства. Участники Особого совещания вынуждены были признать, что механизмов прямого и эффективного административно-политического воздействия на армянского католикоса у российских властей нет. Следствием этого признания стала стратегия невмешательства в выборы католикоса, при этом российское правительство оставляло за собой право не утверждать главой армянской церкви «лиц заведомо враждебных» (л. 21). Также было признано излишним стремление к уравнению количества голосов «российских» и «заграничных» депутатов.

Может показаться, что Особое совещание 1891 г. фактически капитулировало перед вызовом, связанным с политико-административным регулированием Армянской церкви. Но это не совсем так. Наряду с решениями, которые символизировали отказ от идеи манипулирования Эчмиадзином в политических целях, империя пыталась внедрить в практику выборов католикоса важное ограничение. Участники Особого совещания сошлись во мнении, что империя может признавать в качестве духовных депутатов от «турецких» епархий Армянской церкви только тех, которые были посвящены в сан или самим эчмиадзинским католикосом, или заняли соответствующую кафедру с его санкции. Это автоматически повышало влияние Эчмиадзина в армянских епархиях на территории Османской империи, а также ограничивало их самостоятельность. Однако практически реализовать этот принцип было крайне затруднительно. 
К ограничительным мерам следует отнести и рекомендации министерства народного просвещения, которые касались регулирования работы армянских церковно-приходских школ (четвертый вопрос). МНП предлагало организовать управление школами на общих основаниях Положения о начальных училищах (25 мая 1874 г.). Это означало передачу школ Армянской церкви в ведение чиновников МНП. Армянскому духовенству предполагалось оставить только наблюдение за преподаванием «основ» армяно-григорианского вероисповедания (Закона Божия).

«Только этим путем правительство может положить конец возникающим ныне многочисленным бесплодным пререканием по вопросу о названных школах и обеспечить себе уверенность, что массы детей низших классов народонаселения, пользующиеся сими школами, будут воспитываемы в надлежащем духе и направлении», -

подчеркивалось в отзыве МНП (л. 23).

В 1892 г. католикосом был избран подданный османского султана Мкртич (Хримиан), который ранее возглавлял константинопольский армянский патриархат. Эти выборы внешне показали, что Российская империя дистанцировалась от проблемы подбора лояльного католикоса. Мкртич I продолжил независимую политику своих предшественников и уклонялся от следования курсом, определенным российским правительством, вступал в конфликты с региональной и центральной администрацией. Это вновь вернуло МВД и кавказскую администрацию к обсуждению характеристик потенциально лояльного католикоса, столь желаемого империей.

Рефлексии на эту тему посвящено письмо министра внутренних дел Д.С. Сипягина (1899-1902) к главноначальствующему на Кавказе князю Г.С. Голицыну (1896-1905) от 10 декабря 1901 г. Министр отметил, что российское правительство поддерживало избрание «турецких» католикосов с расчетом усилить влияния Эчмиадзина на всем Ближнем Востоке.

«Но, возведенные в сан католикосов турецкие подданные Матеос и Кеворк, сами подпавши под влияние заграничных неблагонамеренных армян, сделались их послушными орудиями для распространения в наших пределах национальной армянской политической пропаганды и вступили в непрерывную борьбу с органами нашего правительства» (л. 27), -

подводил печальный итог такого правительственного курса Д.С. Сипягин. Министр внутренних дел объяснял такое поведение 
католикоса Мкртича I и его предшественников из турецких подданных тем, что

«упомянутые лица, рожденные и воспитанные в Турции, не были в состоянии понять справедливых требований нашего правительства и постоянно пытались применять у нас те деспотические приемы, к которым они привыкли в прежнем своем отечестве» (л. 27).

Д.С. Сипягин видел выход из ситуации противостояния правительства и армянских католикосов в избрании исключительно российских подданных, владеющих русским языком, «знакомых с требованиями цивилизованного государства», а также «привыкших повиноваться предписаниям власти». Министр планировал представить это правило на рассмотрение и утверждение императора.

В ответном письме от 12 марта 1902 г. Г.С. Голицын не согласился с Д.С. Сипягиным. Признав, что владение русским языком и российское подданство - это позитивные стороны биографии кандидата в католикосы, кавказский главноначальствующий сомневался в их решающем значении. Г.С. Голицын предлагал вспомнить католикоса Макария, который, несмотря на российское подданство, русский язык и прочие формальные достоинства, по словам главноначальствующего, «был едва ли не худшим из всех других эчмиадзинских патриархов, не исключая и прибывших из Турции» (л. 29). Из истории с избранием Макария, а также нескольким другим примерам неблагонадежности армянских иерархов Г.С. Голицын делал вывод о бесполезности принципа «русскости», предлагаемого Д.С. Сипягиным. Главноначальствующий считал более уместным оставаться в рамках тактики невмешательства в выборы католикоса, то есть придерживаться решений Особого совещания 1891 г. Кроме того, Г.С. Голицын выражал опасение, что правительственное давление могло только ухудшить положение:

«Не достигнув своей цели, мы в то же время вызвали бы, особенно среди турецких депутатов-избирателей, весьма понятное недовольство и раздражение, а такое настроение в избирательном собрании при свойственной армянам страстности и запальчивости может повести к нежелательным последствиям» (л. 29).

Продолжить дискуссию Д.С. Сипягину не довелось, 2 апреля 1902 г. его убили члены боевой организации эсеров.

Противоположные мнения, высказанные главой МВД и кавказским главноначальствующим, показывают, что у российского правительства не было общепринятой стратегии решения перманентных 
конфликтов в отношениях с армянскими католикосами. Действия правительства и региональной администрации носили скорее реактивный характер, хотя и учитывали предшествующий опыт. Российская империя надеялась получить после новых выборов лояльного католикоса, но всякий раз обманывалась в этих надеждах и расчетах. Новые разочарования провоцировали обсуждение ограничительных и даже откровенно репрессивных мер, однако их планомерное внедрение наталкивалось на правовые и политические препятствия. Положение 1836 г. ограничивало как армянского католикоса, так и имперские власти. Наиболее ярко это проявилось в невозможности отрешения католикоса от эчмиадзинского престола, такая процедура просто не была предусмотрена в российском законе. В политическом отношении грубое административное давление на католикоса было сопряжено с серьезными рисками. Оно могло вызвать рост антироссийских настроений среди армянской диаспоры, а также способствовать радикализации армянского национального движения внутри государства Романовых.

Отчаянная попытка поставить католикоса под контроль империи была предпринята в 1903 г., когда началась конфискация имущества армянской церкви. Необходимо отметить, что эта мера обсуждалась с 1895 г. и вызвала раскол российского управленческого класса. Большинство российских министров во главе с министром финансов С.Ю. Витте выступили против секуляризации Армянской церкви. Николай II поддержал кавказского главноначальствующего Г.С. Голицына, который настаивал на конфискации, и министерское меньшинство. Это решение вызвало масштабный протест армянского населения, предводителями которого стали католикос Мкртич I и Армянская революционная федерация (Дашнакцутюн). В августе 1903 г. (через два месяца после начала секуляризации) католикос Мкртич I выступил с письменным запретом армянскому духовенству содействовать имперской администрации в проведении конфискации церковного имущества. Священников, ослушавшихся запрета, католикос подвергал наказаниям.

14 октября 1903 г. на Г.С. Голицына было совершено покушение. Это произошло во время вечерней прогулки главноначальствующего на коджорской дороге. Нападавших было трое, и один из них успел нанести несколько ударов кинжалом Голицыну по голове. Благодаря расторопности кучера и охраны главноначальствующий не получил серьезных ранений, а нападавшие не успели скрыться. Один из них был убит в перестрелке, двое других смертельно ранены. Как отметила газета «Кавказ», 
«все три злоумышленника принадлежат к низшим классам армянского населения» (Кавказ, 1903, с. 2).

Активное сопротивление не поколебало решимости имперских властей, напротив, разрабатывались новые и еще более жесткие политические акции. 15 октября 1903 г. министр внутренних дел В.К. фон Плеве (1902-1904) представил императору Николаю II всеподданнейший доклад, в котором подверг действия католикоса Мкртича резкой критике. Министр отметил, что католикоса следовало отдать под суд, однако его почтенный возраст и популярность среди армянского населения «представляли для правительства немаловажные неудобства» при организации преследования по закону (РГИА, n.d., ф. 821, оп. 138, д. 90, л. 2).

В.К. фон Плеве предложил несколько практических мер, которые должны были ограничить самостоятельность католикоса и показать решительный настрой правительства. Во-первых, министр внутренних дел испрашивал согласия императора на объявление Мкртичу I высочайшего неудовольствия «за самовольные и противозаконные действия». Во-вторых, рекомендовал объявить католикосу о том, что решение о конфискации церковных имуществ «бесповоротно». В-третьих, предлагалось установить правило, согласно которому назначения преподавателей армяно-григорианских семинарий, настоятелей монастырей, епархиальных викариев согласовывались бы с кавказской администрацией. В-четвертых, В.К. фон Плеве предлагал начать официальное межведомственное обсуждение вопроса о «желательных изменениях в положении патриарха-католикоса». По замыслу министра внутренних дел, кроме него самого в определении нового статуса армянского католикоса должны были принять участие министр иностранных дел и кавказский главноначальствующий. Предложения В.К. фон Плеве были утверждены Николаем II за одним исключением: царь посчитал излишним объявлять Мкртичу І свое неудовольствие (л. 4).

Жесткость некоторых формулировок доклада В.К. фон Плеве свидетельствует о серьезности намерений по трансформации статуса католикоса и формата взаимоотношений с ним. Министр внутренних дел указывал на беспрецедентность внешних атрибутов власти армянских католикосов, «какими не пользуются истинные вселенские патриархи православной нашей церкви». Широкие права и привилегии католикоса, по мнению В.К. фон Плеве, являлись следствием «сознательного политического попустительства». Оппозиционные действия католикосов Макария и Мкртича глава МВД характеризовал 


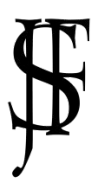

как «чисто папские притязания». Категоричность и решительность В.К. фон Плеве в проведении секуляризации имущества армянской церкви заставляют критически воспринимать сведения из популярных воспоминаний В.И. Гурко, представляющих министра внутренних дел противником конфискации (Гурко, 2000, с. 466).

Политические замыслы МВД, направленные на ограничение прав и привилегий армянских католикосов, находили поддержку у региональной администрации. В декабре 1903 г. оскорбленный покушением, но не испугавшийся Г.С. Голицын предложил изменить статус армянского католикоса и порядок выборов на престол Эчмиадзина. Голицынский проект предусматривал ликвидацию вселенского значения эчмиадзинского католикоса и ограничение его «владений» границами Российского государства. Соответственно, изменялся и порядок выборов католикоса, в которых, согласно предложениям главноначальствующего, должно было участвовать только духовенство Эчмиадзинского монастыря без приглашения каких-либо депутатов от армянских епархий. В письме к В.К. фон Плеве от 25 января 1904 г. Г.С. Голицын кардинальным образом пересмотрел свои взгляды на качества, необходимые претенденту в католикосы. Если в 1902 г. кавказский главноначальствующий критически отзывался о предложении Д.С. Сипягина избирать католикосом только российского подданного, то спустя два года Г.С. Голицын писал следующее:

«...надлежало бы установить, чтобы и кандидаты в патриархи избирались только из русско-подданных (так в тексте - А.У.), воспитанных в России» (РГИА, n.d., ф. 821, оп. 138, д. 80, л. 31).

Предложения Г.С. Голицына повторяли уже упоминавшиеся идеи А.М. Дондукова-Корсакова, которые последний изложил еще в 1882 г. Это важно подчеркнуть, учитывая, что подобные планы будут вновь активно обсуждаться правительством в 1907-1908 гг. В историографии, как правило, указывается, что автором проекта трансформации вселенского армянского католикоса в заурядного епархиального начальника являлся Г.С. Голицын (Верт, 2006, с. 127), но это было сформулировано еще в 1882 г. А.М. Дондуковым-Корсаковым в «Очерке политического состояния Кавказа».

Однако политическое давление на армянское духовенство сменилось в 1905 г. поисками компромисса. По мнению П. Верта, это было связано как с активными волнениями на Южном Кавказе, так и с общим кризисом самодержавия. Такая оценка нуждается в дополнении. Как мы видели, протесты армянского католикоса и вооруженные акции армянских националистов не испугали российскую 
региональную администрацию. Осенью-зимой 1903 г. на фоне антиправительственных протестов начался энергичный обмен мнениями МВД и кавказского главноначальствующего о проекте изменения статуса армянского католикоса. Весной 1905 г. прокурор Эчмиадзинского синода А.Френкель представил записку о деятельности возглавляемого им института для сведения министра В.К. фон Плеве. Документ наполнен критическими оценками деятельности армянских католикосов, которые, по мнению А. Френкеля, «весьма ощутительно доказали правительству всю обманчивость возлагавшихся на них надежд» (РГИА., n.d., ф. 821, оп. 138, д. 90, л. 116). Что свидетельствует о том, что проект изменения статуса католикоса имел все шансы получить законодательное утверждение. В наибольшей степени этому помешало не армянское национальное движение, а убийство министра внутренних дел В.К. фон Плеве 15 июля 1904 г. Кавказский главноначальствующий Г.С. Голицын потерял ключевого союзника в столице. Новый министр внутренних дел П.Д. Святополк-Мирский являлся оппонентом В.К. фон Плеве и не разделял политических идеалов своего предшественника. Дальнейшее продвижение проекта ограничения прав и привилегий армянского католикоса приостановилось.

В январе 1905 г. Г.С. Голицын покинул Кавказ и в Тифлис в статусе наместника прибыл И.И. Воронцов-Дашков (1905-1915). Указ «О восстановлении должности наместника на Кавказе» (Законодательные акты переходного времени, 2010, с. 28-29). Николай II подписал 26 февраля 1905 г. Наместничество восстанавливалось в пределах территории, находившейся под управлением главноначальствующего: наместник управлял и северной, и южной частями российского Кавказа. Он наделялся широкими полномочиями в гражданской $\quad$ и военнополицейской сферах управления; являлся членом Государственного совета, Совета и Комитета министров, главнокомандующим войсками наместничества. Как и ранее, наместник подчинялся непосредственно императору.

Невозможность постоянного участия наместника в заседаниях высших государственных институтов компенсировалось учреждением должности постоянного представителя наместника в Петербурге своеобразного Кавказского комитета в одном лице. Эту должность 13 мая 1905 г. занял барон Э.Ю. Нольде, опытный чиновник, управляющий делами Комитета министров, статс-секретарь.

Почти сразу после приезда в Тифлис И.И. Воронцов-Дашков в личном обращении просил Николая II отменить конфискацию имущества Армянской церкви. Император согласился с доводами наместника, который указывал, что церковная секуляризация способ- 
ствовала росту революционных настроений среди армянского населения края:

«В террористических актах против представителей правительственной власти, прикосновенных так или иначе к отобранию имуществ, участвовали косвенно, если не деньгами, то сочувствием, все кавказские, а быть может и многие российские, армяне» (Воронцов-Дашков, 1907, с. 8-9), -

отмечал И.И. Воронцов-Дашков.

Покровительство, которое наместник оказывал армянам, объясняется поиском социальной опоры в регионе. Восстановление должности наместника с его широкими полномочиями и служебными привилегиями министры встретили без воодушевления. Все знали и помнили, как сложно контролировать кавказских наместников, с одной стороны, облеченных личным доверием царя, а с другой - пользовавшихся популярностью местного населения. И.И. Воронцов-Дашков пытался добиться и первого, и второго. Это была единственная стратегия, позволявшая рассчитывать на административно-политическую свободу действий. Министрам во главе с С.Ю. Витте почти удалось ликвидировать самостоятельность наместника уже в декабре 1905 г. Совет министров подготовил программу административного реформирования края, которая предполагала

«поставить наместника в теснейшую связь с общегосударственною политикою, преследуемою под верховным руководством монарха центральным правительством, объединяемым ныне в Совете министров» (Совет министров Российской империи, 1990, с. 121-125).

И все же И.И. Воронцову-Дашкову удалось устоять благодаря успехам в борьбе с революционными беспорядками. Под впечатлением от хороших новостей с Кавказа Николай II решил поддержать наместника и проводимый им политический курс (ИсмаилЗаде, 2005, с. 129). Документы, которые И.И. Воронцов-Дашков представлял Николаю II, почти неизменно содержали своеобразное кредо всех кавказских наместников - Кавказом нельзя управлять из Петербурга (Кавказ и Российская империя, 2005, с. 493).

Особое положение наместника предопределяло его оппозиционность в отношении административных инициатив и проектов министерской бюрократии и, прежде всего, МВД. После продолжительной чехарды министров внутренних дел (с лета 1904 до весны 1906 г. они успели смениться четырежды) 26 апреля 1906 г. во главе МВД стал П.А. Столыпин (1906-1911). Уже в декабре 1906 г. П.А. Столыпин обратился к «эчмиадзинскому вопросу». Причиной 
внимания министра к проблеме взаимоотношений с католикосами стало, по его собственной характеристике, «хаотическое состояние управления духовными делами Армяно-Григорианской церкви в империи» (РГИА, n.d., ф. 821, оп. 138, д. 90, л. 167). П.А. Столыпин предложил разработать новое положение по управлению Армянской церкви «без присвоения ей той исключительной самостоятельности, которой она пользуется в настоящее время в ущерб государственным интересам» (л. 167).

И.И. Воронцов-Дашков ответил министру 29 января 1907 г., высказался резко против любых законодательных изменений в положении и статусе Армянской церкви до полной стабилизации политического положения на южной окраине империи. После смерти католикоса Мкртича I 29 октября 1907 г. П.А. Столыпин счел удобным «приступить к привидению моего намерения в исполнение» (л. 167). Требуется пояснить, почему ситуация, когда место католикоса оказалось вакантным, представлялась министру внутренних дел подходящей для преобразований, поскольку в историографии заметен дефицит подобных объяснений. П.А. Столыпин разделял вопрос о функциях и правах армянского католикоса и проблему нового административного положения об управлении Армянской церковью. По мнению министра, время между смертью одного католикоса и выборами нового удобно для пересмотра статуса, прав и обязанностей главы армянской церкви. После того, как новый католикос уже на новых условиях возглавит Армянскую церковь, следовало, по замыслу П.А. Столыпина, разработать новое положение по управлению всей церковью. В этом случае новый административный порядок будет согласован с католикосом и таким образом получит все необходимые санкции для полноценного функционирования. Столыпинский план состоял из двух ходов: первый - обеспечить лояльного и контролируемого католикоса; второй - получить покорную и связанную административными ограничениями Армянскую церковь.

Отметим, что проект П.А. Столыпина предусматривал, в том числе, введение процедуры отстранения католикоса от должности, чего так не хватало российской администрации для полноценного давления на несговорчивых армянских пастырей. В целом, проект министра внутренних дел следовал в русле предложений A.M. Дондукова-Корсакова и Г.С. Голицына, но содержал также аргументацию в духе «Записки» А.П. Николаи. Так, подчеркивая необходимость ограничения участия заграничных армян в выборах католикоса, П.А. Столыпин цитировал (впрочем, не ссылаясь) А.П. Николаи и указывал на подавляющий численный перевес представителей 
«турецких» епархий, который приводит к ситуации, когда «избрание патриарха эчмиадзинского совершается не в Эчмиадзине, а в Константинополе» (л. 172).

Предложения МВД натолкнулись на противодействие и критику не только наместника, но также Министерства иностранных дел. Один из первых эпизодов бюрократического противостояния произошел уже в декабре 1907 г., когда министр иностранных дел А.П. Извольский (1906-1910) переслал в МВД депеши российского посла в Константинополе И.А. Зиновьева. В этих документах пересказывалась просьба константинопольского армянского патриарха Малахии назначить новые выборы католикоса на 1 мая 1908 г. П.А. Столыпин категорично отверг обоснованность просьбы патриарха Малахии и даже отметил свое подозрение в том, что

«возбуждение этого ходатайства имело место не без участия Эчмиадзина, который, опасаясь едва ли для него неожиданного решения правительства о пересмотре Положения об Армяно-Григорианской церкви и католикоса в России, стремится всеми средствами сократить период вакантности патриаршего престола» (л. 185).

В марте 1908 г. МИД направил МВД официальный отзыв на предложения по реформе управления Армянской церкви. Министр иностранных дел выступил резко против намеченной МВД программы. А.П. Извольский счел, что ликвидация вселенского статуса армянского католикоса - крайне непродуманная и опасная акция сразу по двум причинам. Во-первых, пересмотр российского законодательства, по мнению главы МИД, не гарантировал его реализации. А.П. Извольский обоснованно отмечал, что вселенский статус Эчмиадзина обеспечен армянской религиозно-церковной традицией, которую перемены российских законов будут не в состоянии поколебать. Во-вторых, как подчеркивалось в отзыве А.П. Извольского,

«отнятие у Эчмиадзинского престола его вселенского характера явилось бы нарушением прямых государственных интересов России» (л. 201).

Под этим императивом А.П. Извольский понимал как кризисное состояние российского Кавказа, так и нестабильные отношения с Османской империей, которые грозили новым конфликтом. Здесь контраргументы министра иностранных дел и кавказского наместника сходились - пересмотр Положения 1836 г. мог вызвать новый революционный кризис на южной окраине империи, а также лишить Россию возможности использовать фактор Эчмиадзина в дипломатической борьбе с Османской империей. 
Единодушие и сильные аргументы МИД и наместника заставили МВД отказаться от большей части задуманного, но П.А. Столыпин не думал сдаваться. Возможно, настойчивость министра внутренних дел основывалась на некотором разладе внутри ведомства А.П. Извольского. В своей выдающейся статье П. Верт отметил, что, прежде чем раскритиковать проект МВД, А.П. Извольский запросил мнение посла в Константинополе И.А. Зиновьева (Верт, 2006, с. 129). Может сложиться впечатление, что именно И.А. Зиновьев сформулировал основные выпады против столыпинского проекта. Однако ситуация оказалась сложнее. Еще 22 декабря 1907 г. директор департамента духовных дел иностранных исповеданий МВД В.В. Владимиров частным образом запросил мнение посла И.А. Зиновьева о проекте трансформации статуса католикоса и реформе управления армянской церковью (РГИА, n.d., ф. 821, оп. 138, д. 90, л. 187). Необходимо отметить, что И.А. Зиновьев являлся одним из наиболее опытных российских дипломатов. Он работал в Персии, Средней Азии, руководил Азиатским департаментом МИД. В своем ответе на запрос МВД И.А. Зиновьев почти во всем поддержал проект П.А. Столыпина:

«...было бы как нельзя более желательно не упоминать в нашем законодательстве о вселенском значении католикоса и подвергнуть пересмотру узаконения, определяющие права католикоса и обязанности его к русскому правительству» (л. 190), -

\section{отмечал посол.}

Тем не менее, протест МИД и наместника заставил МВД сменить позицию. В последующем обмене мнениями П.А. Столыпин отступил от намерения кардинального пересмотра Положения 1836 г. и предлагал довольно умеренную программу, которая включала три пункта: первый - католикос должен был знать русский язык; второй голоса российских и заграничных армян на выборах должны быть уравновешены; третий - привилегии католикоса должны быть уточнены. Как видно, в этих предложениях не было ничего нового, их аргументация повторяла содержание записок Г.С. Голицына и планов Д.С. Сипягина и В.К. фон Плеве. Но даже эти меры были поставлены под сомнение А.П. Извольским и И.И. ВоронцовомДашковым. По их мнению, условие обязательного знания русского языка претендентами на престол католикоса, с одной стороны, никак не гарантировало лояльности главы Армянской церкви, а с другой подрывало вселенское значение католикоса. МИД выступало против уравновешивания голосов депутатов до выборов, но выражало готовность пойти на это после проведения процедуры. Причины такой 
позиции крылись в опасности возникновения обвинений в том, что участие турецких армян в выборах католикоса было умышленно ограничено по политическим мотивам. И, наконец, А.П. Извольский, в принципе, не возражал против уточнения административных прав и привилегий армянского католикоса, однако ссылался на необходимость дополнительной правовой разработки этого вопроса.

В августе 1908 г. Совет министров принял решение не вводить никаких новелл в Положение 1836 г. Выборы католикоса проводились по традиционным правилам, с одним лишь незначительным дополнением: на последней ступени выборов голоса подавались тайно, что позволяло депутатам чувствовать себя свободнее (Верт, 2006, с. 130-131). П.А. Столыпин был вынужден согласиться с тем, что преобразование порядка выборов католикоса и трансформация его статуса могут усилить политическую турбулентность и привести к эскалации насилия на южной окраине империи.

Новым католикосом в 1908 г. стал Маттеос II, который ранее возглавлял константинопольский патриархат Армянской церкви. Маттеос II пользовался огромной личной популярностью как защитник турецких армян. Вполне возможно, что популярный католикос мог выбрать независимую линию поведения и доставить имперской администрации множество неудобств. Но Маттеос II скончался через полтора года. В 1911 г. главой эчмиадзинского престола стал Геворг V, который нес службу на протяжении 18 лет. П.А. Столыпин так и не смог убедить Совет министров в необходимости преобразований системы управления Армянской церкви. После убийства Столыпина 5 сентября 1911 г. этот вопрос и вовсе исчезает из политической повестки.

\section{ВЫВОДЫ}

Взаимное непонимание и подозрительность в отношениях между Российской империей и Армянской церковью присутствовали с момента присоединения Восточной Армении в 1828 г. Несмотря на тщательную подготовку, «Положение» 1836 г. не стало универсальным средством гармоничного сосуществования. Многое определялось наличием у российских администраторов неформальных связей с Эчмиадзином. В качестве примера здесь следует указать на успешный опыт первого кавказского наместника М.С. Воронцова, которому удалось выстроить доверительные отношения с католикосом Нерсесом V.

В дальнейшем отношения балансировали между холодной официальностью и откровенной враждебностью. Российская империя 
рассчитывала использовать католикосов во внешнеполитических целях, связанных с давлением на Османскую империю и гипотетическим участием в разделе османского наследства. Однако католикосы своими независимыми действиями раз за разом демонстрировали призрачность этих надежд. В 1880-е гг. представители региональной администрации предложили несколько вариантов решения «эчмиадзинского вопроса». Умеренная программа была представлена в «Записке» А.П. Николаи (1883 г.), предлагавшего наладить контакты с провинциальными армянскими епархиями в Османской империи для нейтрализации «электоральной» гегемонии константинопольских армян. Радикальные преобразования по ликвидации вселенского статуса католикоса были изложены в «Очерке» А.М. Дондукова-Корсакова (1882 г.). Последующие проекты имперских властей или прямо основывались на этих документах, или повторяли артикулированные в них принципы и положения. Российское правительство на рубеже XIX-XX вв. попыталось поставить Армянскую церковь под контроль, однако революционные протесты и внешнеполитические мотивы заставили Петербург отказаться от репрессивной политики. Но это были не единственные причины показательного бессилия имперской власти.

История взаимоотношений Российского государства и Армянской церкви в XIX - начале XX вв. показывает, что различные акторы имперской политики имели разные представления об оптимальной модели взаимодействия с Эчмиадзином. Водоразделы проходили не только между различными ведомствами (МВД против МИД), но и внутри них, где отдельные чиновники могли придерживаться в каждом конкретном случае «антиведомственных» взглядов. Все это препятствовало административной консолидации, замедляло реакцию империи на важные политические вызовы, втягивало имперские структуры в затяжные служебно-иерархические противостояния. «Эчмиадзинский вопрос» и правительственные дискуссии вокруг него отчасти показывают административный паралич самодержавия и декомпенсацию системы власти в Российской империи начала XX в.

\section{БЛАГОДАРНОСТИ}

Статья подготовлена за счет средств Российского научного фонда проект 17-78-20117 «Национальные окраины в политике Российской империи и русской общественной мысли». 


\section{Список литературы}

Ueno, M. (2013). "For the Fatherland and the State": Armenians Negotiate the Tanzimat Reforms. International fournal of Middle East Studies, 45 (1), 93-109. doi: 10.1017/ S0 020743812001274

Ueno, M. (2016). Religious in Form, Political in Content? Privileges of Ottoman NonMuslims in the Nineteenth Century. Journal of the Economic and Social History of the Orient, 59 (3), 408-441. doi: 10.1163/15685 209-12341403

Акты, собранные Кавказской археографической комиссией (1878). Тифолис: Типография Главного управления наместника кавказского.

Акты, собранные Кавказской археографической комиссией (1885). Тифлис: Типография Канцелярии главноначальствующего гражданской частью на Кавказе.

Амбарцумов, И. В. (2010). Армяно-грегорианская церковь и Российское государство в конце XIX - начале XX века. Вестник Тверского государственного университета. Серия: История, (4), 115-127.

Амбарцумов, И. В. (2012). Эчмиадзинские католикосы и их влияние на общественно-политическую жизнь Армении (1892-1912). Вестник Тверского государственного университета. Серия: История, (3), 76-87.

Вартанян, В. Г. (1999). Армяно-григорианская иерковь в конфессиональной политике России (последняя треть XVIII - первая половина XIX вв.). (Диссертация на соискание ученой степени кандидата исторических наук). Ростов-на-Дону.

Верт, П. (2006). Глава церкви, подданный Императора: Армянский Католикос на Перекрестке Внутренней и Внешней Политики Империи, 1828-1914. Ab Imperio, (3), 99-138. doi: 10.1353/imp.2006.0107

Верт, П. (2012). Православие, инославие, иноверие: очерки по истории религиозного разнообразия Российской империи. Москва: Новое литературное обозрение.

Воронцов-Дашков, И. И. (1907). Всеподданнейшая записка по управлению Кавказским краем генерал-адъютанта графа Воронщова-Дашкова. Санкт-Петербург: Государственная типография.

Гурко, В. И. (2000). Черты и силуэты прошлого: правительство и общественность в иарствование Николая II в изображении современника. Москва: Новое литературное обозрение.

Ерицов, А. Д. (1898). Патриарх всех армян Нерсес V-й и князь Михаил Семенович и княгиня Елизавета Ксавериевна Воронцовы, в их частной переписке. Тифолис: Скоропечатня М. Мартиросянца.

Законодательные акты переходного времени. 1904-1908 гг.: Сб. Законов, манифестов, указов Правительствующему сенату, рескриптов и положений Комитета министров, относящихся к преобразованию государственного строя России (2010). Москва: Государственная публичная историческая библиотека.

Исмаил-Заде, Д. И. (2005). И. И. Воронщов-Дашков. Кавказский наместник. Москва: Центрполиграф. 
Кавказ и Российская империя: Проекты, идеи, иллюзии и реальность. Начало XIXначало XX вв. (2005). Санкт-Петербург: Издательство журнала «Звезда».

Кавказ (1903). (275).

Кумпан, Е. Н. (2019). Армянская апостольская церковь в религиозной политике Российской империи: процесс инкорпорации и дискуссия о полномочиях католикоса. Этнос и общество в контексте межнациональных отношений: материаль Всероссийской научно-практической конференции, 185-198. Ставрополь: ИП Дорофеев В.Ю.

Лазарян, С. С. (2018). Архиепископ Нерсес и российские власти в 20-30-е годы XIX века: проблемы взаимопонимания. В Кавказ в геополитических интересах региональных и мировых держав: сб. науч. ст., посвященный памяти выдающегося ученого-кавказоведа и большого друга армянского народа Виктора Владимировича Черноуса. Ростов-на-Дону: ДГТУ-Принт.

Месропян, А. В. (2012). Церковная политика царской России в Восточной Армении в первой половине XIX века. Система ценностей современного общества, (23), $86-90$.

Петросян, Ю. А. (2017). Османская империя. Могущество и гибель. Санкт-Петербург: Наука.

Полное собрание законов Российской империи. Собрание II. (1837). Санкт-Петербург: Типография II Отделения Собственной его императорского величества канцелярии.

Российский государственный исторический архив (РГИА) (б. д.-а). Ф. 821. On. 138. Д. 77.

Российский государственный исторический архив (РГИА) (б. д.-b). Ф. 821. On. 138. Д. 77.

Российский государственный исторический архив (РГИА) (б. д.-с). Ф. 821. On. 138. Д. 79.

Российский государственный исторический архив (РГИА) (б. д.-d). Ф. 821. On. 138. Д. 80.

Российский государственный исторический архив (РГИА) (б. д.-е). Ф. 821. On. 138. Д. 80.

Российский государственный исторический архив (РГИА) (б. д.-f). Ф. 821. On. 138. Д. 87.

Российский государственный исторический архив (РГИА) (б. д.-g). Ф. 821. On. 138. Д. 90.

Российский государственный исторический архив (РГИА) (б. д.-h). Ф. 932. On. 1. Д. 296.

Российский государственный исторический архив (РГИА) (б. д.-і). Ф. 1250. On. 2. Д. 12.

Российский государственный исторический архив (РГИА) (б. д.-ј). Ф. 1268. On. 1. Д. 825 . 
Российский государственный исторический архив (РГИА) (б. д.-k). Ф. 1268. On. 3. Д. 22.

Рыбаков, А. Л. (2012). В «области кесаря»: проблемы статуса и структуры Грузинской православной церкви после отмены автокефалии (первая половина XIX века). В Конфессия, империя, нащия: религия и проблема разнообразия в истории постсоветского пространства. Москва: Новое издательство.

Совет министров Российской империи 1905-1906 г2. Документы и материаль (1990). Ленинград: Наука.

\section{References}

Acts collected by the Caucasian Archaeographic Commission (1878). Tiflis: Printing House of the Main Administration of the Viceroy of the Caucasus (In Russian).

Acts collected by the Caucasian Archaeographic Commission (1885). Tiflis: Typography of the Office of the Commander-in-Chief of the Civil Part in the Caucasus (In Russian).

Ambartsumov, I. V. (2010). The Armenian Gregorian Church and the Russian State in the Late 19th and Early 20th Centuries. Vestnik of Tver State University. Series: History, (4), 115-127. (In Russian).

Ambartsumov, I. V. (2012). The Catholicoses of Etchmiadzin and their influence on the social and political life of Armenia (1892-1912). Bulletin of Tver State University. Series: History, (3), 76-87 (In Russian).

Caucasus. (1903). (275) (In Russian).

Complete Collection of Laws of the Russian Empire. Collection II. (1837). St. Petersburg: Printing Office II of His Imperial Majesty's Own Chancellery (In Russian).

Gurko, V. I. (2000). Features and Silhouettes of the Past: The Government and Public in the Reign of Nicholas II as Portrayed by a Contemporary. Moscow: New Literary Review (In Russian).

Ismail-Zadeh, D. I. (2005). I. I. Vorontsov-Dashkov. Viceroy of the Caucasus. Moscow: Tsentrpoligraf (In Russian).

Kumpan, E. N. (2019). The Armenian Apostolic Church in the Religious Policy of the Russian Empire: The Process of Incorporation and the Discussion of the Powers of the Catholicos. Ethnicity and Society in the Context of Interethnic Relations: Materials of the All-Russian Scientific and Practical Conference, 185-198. Stavropol: IP Dorofeev V. Yu. (In Russian).

Lazarian, S. S. (2018). Archbishop Nerses and the Russian authorities in the 1920s and 1930s: Problems of Mutual Understanding. In The Caucasus in geopolitical interests of regional and world powers: Collection of Scientific Articles. The article is dedicated to the memory of the outstanding scientist and great friend of the Armenian people Viktor Vladimirovich Chernous. Rostov-on-Don: DSTU-Print (In Russian).

Legislative Acts of the Transitional Time. 1904-1908: Collection of Laws, Manifestos, Decrees to the Governing Senate, Rescripts and Regulations of the Committee of Ministers 
Regarding the Transformation of the Russian State System.. (2010). Moscow: State Public Historical Library (In Russian).

Mesropian, A. V. (2012). Tsarist Russian ecclesiastical policy in Eastern Armenia in the first half of the 19th century. The value system of modern society, (23), 86-90.

Petrosyan, Yu. (2017). The Ottoman Empire. Power and Destruction. St. Petersburg: Nauka (In Russian).

Russian State Historical Archive (RSHA). (n. d.-a). F. 821. Inv. 138. C. 77 (In Russian).

Russian State Historical Archive (RSHA). (n. d.-b). F. 821. Inv. 138. C. 77 (In Russian).

Russian State Historical Archive (RSHA). (n. d.-c). F. 821. Inv. 138. C. 79 (In Russian).

Russian State Historical Archive (RSHA). (n. d.-d). F. 821. Inv. 138. C. 80 (In Russian).

Russian State Historical Archive (RSHA). (n. d.-e). F. 821. Inv. 138. C. 80 (In Russian).

Russian State Historical Archive (RSHA). (n. d.-f). F. 821. Inv. 138. C. 87 (In Russian).

Russian State Historical Archive (RSHA). (n. d.-g). F. 821. Inv. 138. C. 90 (In Russian).

Russian State Historical Archive (RSHA). (n. d.-h). F. 932. Inv. 1. C. 296 (In Russian).

Russian State Historical Archive (RSHA). (n. d.-i). F. 1250. Inv. 2. C. 12 (In Russian).

Russian State Historical Archive (RSHA). (n. d.-j). F. 1268. Inv. 1. C. 825 (In Russian).

Russian State Historical Archive (RSHA). (n. d.-k). F. 1268. Inv. 3. C. 22 (In Russian).

Rybakov, A. L. (2012). In the "Region of Caesar": Problems of the Status and Structure of the Georgian Orthodox Church after the Abolition of Autocephaly (First Half of the 19th Century). In Confession, Empire, and Nation: Religion and the Problem of Diversity in Post-Soviet History. Moscow: New Publishing House (In Russian).

The Caucasus and the Russian Empire: Projects, Ideas, Illusions and Reality. Early 19th-early 20th centuries. (2005). St. Petersburg: Zvezda Magazine Publishers (In Russian).

The Council of Ministers of the Russian Empire in 1905-1906. Documents and materials (1990). Leningrad: Nauka (In Russian).

Ueno, M. (2013). "For the Fatherland and the State": Armenians Negotiate the Tanzimat Reforms. International fournal of Middle East Studies, 45 (1), 93-109. doi: 10.1017/ S0 020743812001274

Ueno, M. (2016). Religious in Form, Political in Content? Privileges of Ottoman NonMuslims in the Nineteenth Century. Journal of the Economic and Social History of the Orient, 59 (3), 408-441. doi: 10.1163/15685 209-12341403

Vartanyan, V. G. (1999). The Armenian Gregorian Church in Russian confessional policy (the last third of the 18th century and the first half of the 19th century). ( $\mathrm{PhD}$ in History Thesis). Rostov-on-Don (In Russian).

Vorontsov-Dashkov, I. I. (1907). Adjutant General Count Vorontsov-Dashkov's all-submitting note on administration of the Caucasian Region. St. Petersburg: State Printing House (In Russian). 


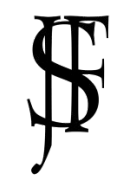

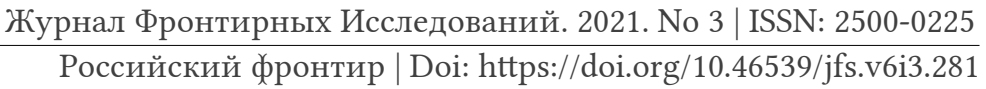

Werth, P. (2006). Head of the Church, Subject of the Emperor: The Armenian Catholicos at the Crossroads of the Inner and Outer Politics of the Empire, 1828-1914, 1828-1914. Ab Imperio, (3), 99-138. doi: 10.1353/imp.2006.0107 (In Russian).

Werth, P. (2012). Orthodoxy, Non-Orthodoxy, and Other Religions: Essays on the History of Religious Diversity in the Russian Empire. Moscow: New Literary Review (In Russian).

Yeritsov, A. D. (1898). Patriarch of All Armenians Nerses V and Prince Mikhail Semenovich and Princess Elizabeth Xaverevna Vorontsov, in their private correspondence. Tiflis: M. Martirosyants Printing House (In Russian). 